\title{
Implementation of Signature Validity On Electronic Documents in Proof Indonesian Civil Procedure Law
}

\author{
Nurul Khotimatul Khusniyah*) and Widayati**) \\ *) Bawaslu Legal Analyst of Jepara, E-mail: nurulhbs@gmail.com \\ ${ }^{* *}$ Faculty of Law, Sultan Agung Islamic University (UNISSULA) Semarang
}

\begin{abstract}
.
This study aims to identify and analyze the acknowledgment of signatures on an electronic document in the evidence of civil procedural law in Indonesia, and to find out and analyze the implementation of civil dispute resolution submitted by the parties by means of electronic documents signed with digital signatures. The method used in this research is to use an empirical juridical approach. Electronic documents, in this case digital signatures, can be used as evidence in court, which is an extension of the evidentiary law in Indonesia after the ITE Law, but only has the power of proof as an underhand deed not as an authentic deed. In the process of settling a lawsuit for civil proceedings through litigation media, it is carried out amicably first by means of a peace made by the party concerned without the assistance of an authorized official. Efforts to settle through non-litigation media can be carried out in three ways, including arbitration, negotiation, and mediation.
\end{abstract}

Keywords: Electronic; Evidence; Documents; Signatures.

\section{Introduction}

Information and Communication Technology has become a new thing for people to obtain information autonomously. There is no limit to the information barrier due to the strong initiative of individuals who want to know more about what is happening around them. Everyone has easy access to information anywhere in the world.

The pace of development of information technology in the Uber Civilization certainly has an effect on the Supreme Court. Previously, case administration was carried out manually which took a long time and was high in cost, information technology has accelerated, simplified and reduced the cost of administering cases within the Supreme Court.

Engagement law is part of property law. In the Civil Code (KUHPer), assets are regulated in book III which includes the relationship between people and things, the relationship between people and people. While the law that regulates the relationship between people and people is regulated in book III on engagement ${ }^{1}$.

\footnotetext{
${ }^{1}$ Chuasanga A., Ong Argo Victoria, 2019, "Legal Principles Under Criminal Law in Indonesia and $\begin{array}{llllll}\text { Thailand", Jurnal Daulat Hukum, Vol 2, No } 1 & \text { (2019) }\end{array}$ http://jurnal.unissula.ac.id/index.php/RH/article/view/4218
} 
Engagement is a translation of the Dutch term "verbintenis". Engagement means something that binds one person to another. ${ }^{2} \mathrm{~A}$ binding thing is a legal event that can be in the form of actions, events, and circumstances. The legal event creates a legal relationship. The engagement is born because of an agreement or because of the law. ${ }^{3}$

In 2008 Indonesia had legal rules to regulate these problems, namely with the enactment of Act No. 11 of 2008 concerning Information and Electronic Transactions which was updated by Act No. 19 of 2016. Based on Article 18 in conjunction with Article 7 in conjunction with Article 11 of the ITE Law, the strength of proof of the electronic document which is signed with a digital signature is the same as the strength of proof of an authentic deed made by an authorized public official.

However, this rule contradicts as stated in Article 1 paragraph (7) of Act No. 2 of 2014 concerning Amendments to Act No. 30 of 2004 concerning the Position of a Notary which states that a notary deed, hereinafter referred to as a deed, is an authentic deed made by or before Notary according to the form and procedure stipulated in this Law. Meanwhile, the definition of an authentic deed based on Article 1868 of the Civil Code is a deed which, in the form determined by law, is made by or in the presence of public officials in power for that purpose at the place where the deed was made.

As a result of a conflict of these rules, if one of the parties files a lawsuit with electronic document evidence signed with an electronic signature as evidence, then in resolving the dispute in court, the judge is required to dare to make legal breakthroughs, because he is the most powerful in deciding a case and because he is also the one who can give a verdict van de rechter, which can indirectly be based on a written or unwritten legal regulation.

\section{Research Methods}

The research method is a way of doing things with a mature way of thinking to achieve a goal of searching, recording, formulating and analyzing to compiling a report. ${ }^{4}$ The approach method used in this research is a sociological juridical approach. ${ }^{5}$ The research specification used is descriptive-analytical, which is the author trying to describe existing realities or existing facts and describe a problem that has occurred in the implementation of the validity of electronic signatures in civil procedural law. The data needed in this study are primary data, secondary data, and tertiary data. In analyzing the data the author uses a qualitative method, in which the author describe systematically so as to answer the whole problem with the research results constructed in a conclusion.

\footnotetext{
${ }^{2}$ Abdulkadir Muhammad, 2000, Hukum Perdata Indonesia. Bandung : PT Citra Aditya Bakti, p.198

3 Oedharyo Soimin, 1999, Kitab Undang-Undang Hukum Perdata, Jakarta: Sinar Grafika, p.313

${ }^{4}$ Kustriyo and Aryani Witasari, "Abuse of Authority in Position and Redemption of Credit Fictitious Apparatus for Civil State (ASN) PD. Bank Perekreditan Rakyat (BPR) Sumber, Cirebon District", Jurnal Daulat Hukum Vo $1 \quad$ No 33 (2018) url: http://jurnal.unissula.ac.id/index.php/RH/article/view/3396

5Zainudin Ali, (2014), Metode Penelitian Hukum, Jakarta: Sinar Grafika, p. 105.
} 


\section{Results and Discussion}

\subsection{Signature Recognition on an Electronic Document in Proof of Civil Procedure Law in Indonesia}

E-commerce is a trade/purchase transaction of goods and services carried out by exchanging information/data using alternatives other than written media. What is meant by alternative media here is electronic media, especially the internet. In addition, Article 1 paragraph (2) of the ITE Law explains that electronic transactions are legal relations carried out through computers, computer networks, or other electronic media.

An e-commerce agreement made by the interested parties in the form of an electronic document, if one of the parties violates the agreement/defaults from one of the parties, the aggrieved party can sue to the Court with electronic document evidence.

M. Yahya Harahap explained that proof is a provision that contains outlines and guidelines regarding procedures justified by law to prove the guilt that has been charged to the defendant. Evidence is a provision that regulates the evidence that is justified by law and regulates the evidence that may be used by judges to prove the guilt of the accused. ${ }^{6}$

Proving is convincing the judge of the truth of the arguments or arguments put forward in a dispute, so that it appears that proof is only needed in a dispute or case before a judge or court ${ }^{7}$ while the evidence is the provisions that contain the outlines and guidelines on the ways that are justified by law to prove the guilt that has been charged to the defendant. Then M Yahya Harahap argues that proof is also a provision that regulates evidence that is justified by law and may be used by judges to prove the guilt of the accused.

The regulation of electronic evidence must be based on the system and principles of procedural law in force in Indonesia. Subekti stated that the law of proof is a series of disciplinary rules that must be heeded in carrying out a battle before a judge, between two parties who are seeking justice. ${ }^{8}$ Hari Sasangka defines the law of evidence as part of the procedural law that regulates various types of evidence that are legal according to the law, the system adopted in proof, the requirements and procedures for submitting such evidence and the judge's authority to accept, reject and evaluate a piece of evidence. ${ }^{9}$

Referring to the provisions regarding evidence regulated in the procedural law applicable in Indonesia, there must be a testing tool for electronic evidence so that the evidence can be declared valid at trial, the same as for other evidence, namely formal requirements and material requirements. These requirements are determined based on the type of electronic evidence referred to in the original form or in its printed form.

\footnotetext{
6Eddy O S Hiariej, 2012, Teori dan Hukum Pembuktian, Jakarta : Erlangga, p. 2

7 Sulaiman, Nur Arifudin, and Liliy, 2020, "Kekuatan Hukum Digital Signatur Sebagai Alat Bukti yang Sah Ditinjau dari Hukum Acara Perdata”, Jurnal Risalah Hukum Vol 16 No 2, p.96

8Subekti, 1995, Hukum Pembuktian, Jakarta : Pradnya Paramita, p. 2

${ }^{9}$ Hari Sasangka and Lily Rosita, 2003, Hukum Pembuktian dalam Perkara Pidana, Bandung : Mandar Maju, p. 10
} 
An electronic document is declared valid if it uses a security system that can be accounted for in accordance with the development of information technology, and fulfills the following minimum requirements: ${ }^{10}$

- Can display information and/or electronic documents in their entirety in accordance with the retention period stipulated by the laws and regulations;

- can protect the availability, integrity, authenticity, confidentiality, and accessibility of electronic information in the operation of the electronic system;

- can operate in accordance with procedures or instructions in the operation of the electronic system;

- equipped with procedures or instructions announced in language, information, or symbols that can be understood by the party concerned with the operation of the electronic system; and

- have a sustainable mechanism to maintain the novelty, clarity, and accountability of procedures or instructions.

Verification of letter evidence in a computer has two categories, including: ${ }^{11}$

- If a computer system has been certified by an authorized body, then the computer printout results can be trusted to authenticate.

- Evidence of certification from the authorized body can be categorized as documentary evidence, because it is made by and or authorized official.

In the second point as mentioned above, it is explained that the strength of proof of electronic documents is the same or parallel to letters (written evidence), but the form of the letter in question is not detailed more clearly. Because according to Sudikno Mertokusumo's opinion, the letter is divided into two, namely the letter in the form of a deed and other documents that are not a deed. And the deed itself is still further divided into an authentic deed and a private deed. 12

Regarding evidence in electronic form, Michael Chissick and Akistair Kelman state that there are three types of evidence made with computers, namely: ${ }^{13}$

- Real Evidence (conclusive evidence)

- Hearsay Evidence (evidence in the form of news from other people)

- Derived Evidence

Based on the understanding of Article 1 point 4 of the ITE Law, the form of electronic documents is very diverse, depending on the intended use of the document itself. If the electronic document is only in the form of ordinary information, then the document is included in an ordinary letter or a private deed because it is made improvised and will not be used as evidence later. However, if it turns out that the document is intended as an authentic document, then the document must meet several requirements. The main requirement for an

\footnotetext{
${ }^{10}$ Dewi Asimah, 2020, "Menjawab Kenadal Pembuktian dalam Penerapan Alat Bukti Elektronik", Jurnal Hukum Peratun Vol 3 No 2. p. 102

${ }^{11}$ Edmon Makarim, 2003, Kompilasi Hukum Telematika, Divisi Buku Perguruan Tinggi, Jakarta:Rajagrafindo Persada. p. 419

${ }^{12}$ Maslikan \& Sukarmi, 2018, "Kewenangan Notaris Dalam Pembuatan Akta Otentik Berkaitan Dengan Kontrak Kerjasama , Jurnal Akta 5 (1), p. 12

${ }^{13}$ Triyanti, 2015, "Kekuatan Pembuktian Dokumen Elektronik Sebagai Pengganti Minuta Akta Notaris", Jurnal Repertorium Vol 11 No 2. p.24
} 
electronic document to be declared as valid evidence is the use of an electronic system that has received electronic certification from the government (Articles 1316 of the ITE Law). Another requirement is to put an electronic signature, put it in a standard electronic contract, and so on.

Salam Abdul, although electronic documents can be used as evidence in court, which is an extension of the law of evidence in Indonesia after the ITE Law, they only have the power of proof as an underhand deed. ${ }^{14}$

From a technical perspective, the authenticity of an electronic document is actually determined by the accountability or reliability of the electronic system itself. This is in line with the opinion of Smith, a computer security expert who stated that technically, electronic information is trustworthy because it comes from a trustworthy system. ${ }^{15}$

\subsection{Implementation of Settlement of Civil Disputes Submitted by the Parties with Electronic Documents Signed with a Digital Signature}

The new verification process occurs when there is a dispute between the parties, the dispute itself is usually resolved by one of the clauses in the agreement. Generally, the settlement is through litigation or non-litigation. ${ }^{16}$

Based on Article 38 paragraph (1) of the ITE Law, it is stated that anyone can file a lawsuit against a party that operates an electronic system and/or uses information technology that causes losses, a civil lawsuit can be filed, with the provisions of this article, it can protect the aggrieved party to claim their rights are violated by other parties. Settlement of civil disputes can be through litigation or non-litigation.

\section{Dispute Resolution Through Litigation}

Settlement of the dispute, the aggrieved party can file a lawsuit, according to the provisions of Article $144 \mathrm{RBg}$ or Article $120 \mathrm{HIR}$, how to file the lawsuit can be submitted in writing or orally to the Head of the District Court. ${ }^{17}$

In the process of resolving this civil procedure lawsuit, it can be carried out amicably first by means of a peace made by the party concerned without the assistance of an authorized official. This peace is made with an underhand deed or peace is made with the involvement or assistance of an authorized official, such as a notary, this peace is made with an authentic deed, and the implementation of the peace can be through a court, which is ended with a peace decision. At the proof stage, the parties must submit strong evidence to convince the judge, in a lawsuit in court.

Evidence of an electronic transaction to convince judges at trial is an electronic document in which there is an agreement of the parties, the electronic document can be in analog, digital, electronic, or optical form, or the data in the

\footnotetext{
${ }^{14}$ V Letsoin, 2010, Pengakuan Tandatangan Pada Dokumen Elektronik Dalam Pembuktian Hukum Acara Perdata di Indonesia, Jurnal Sasi Vol 16 No 2. p. 56

${ }^{15}$ Edmon Makarim, (2013), Notaris dan Transaksi Elektronik, Jakarta: Rajawali Press. p. 16

${ }^{16}$ Abdul Halim Barkataullah and Teguh Prasetyo, (2005), Bisnis E-Commerce Studi Sistem Keamanan dan Hukum di Indonesia, Yogyakarta : Pustaka Pelajar, p. 120

${ }^{17}$ Ahmaturrahman, (2005), Hukum Acara Perdata di Indonesia, Palembang : FH Press.p. 97
} 
electronic document is printed/photocopy, and also the signature of the public key, or a copy of the digital certificate.

Signatures generated by a public key infrastructure provided by a licensed Certification Authority (CA) should be immediately admissible in court without needing to be authenticated. Digital certificates can be used to identify the legitimacy of the transacting parties and affix the digital signature. The certificate is issued by an institution that is trusted to manage the data related to the certificate.

\section{Dispute Resolution Through Non Litigation}

Dispute resolution through the courts takes a long time, this can harm many parties, apart from litigation, dispute resolution can also be done through nonlitigation. Based on Article 39 paragraph (2) of the ITE Law, the disputing parties can settle through arbitration or other alternative dispute resolution institutions in accordance with statutory provisions. Settlement out of court can be done in several ways, including: 18

- Arbitration, which is a method of resolving civil disputes outside a general court based on an arbitration agreement made in writing by the parties to the dispute, with the assistance of the Arbitrator, who completes the decision, and the decision has permanent legal force;

- Negotiation, namely the settlement of the dispute, based on the agreement between the two parties to the dispute without asking for assistance from a third party;

- Mediation, namely the settlement of the dispute with the help of a mediator, namely a third party, but this third party only provides an opinion, not a decision on the dispute.

The first process to resolve the dispute is through negotiation first, but if there is no agreement between the two parties, it will be resolved through the court that has been agreed in the agreement, this is because the dispute resolution can be resolved in a short time, so that the settlement through the Court not the first choice.

For civil cases, the parties can be given the freedom to settle the case through litigation, or non-litigation, but often, the settlement through non-litigation (except arbitration), the parties do not carry out their obligations as a result of the agreement to settle the case, and because they do not implement the decision of the agreement of the parties, the aggrieved party sues to the court.

\section{Clossing}

Recognition of digitally signed electronic documents can be used as evidence in court, which is an extension of the law of proof in Indonesia after the ITE Law, but only has the power of proof as an underhand deed not as an authentic deed. Meanwhile, the implementation of electronic document dispute resolution that is signed using a digital signature in civil procedural law can be through litigation or non-litigation media. In the process of settling a lawsuit for civil proceedings

18Ibid, p. 33

Implementation of Signature Validity On Electronic Documents in Proof Indonesian Civil 
through litigation media, it is carried out amicably first by means of a peace made by the party concerned without the assistance of an authorized official. Efforts to settle through non-litigation media can be carried out in three ways, including arbitration, negotiation, and mediation.

\section{References}

\section{Journals:}

[1] Chuasanga A., Ong Argo Victoria. (2019). "Legal Principles Under Criminal Law in Indonesia and Thailand", Jurnal Daulat Hukum, Vol 2, No 1 (2019) http://jurnal.unissula.ac.id/index.php/RH/article/view/4218

[2] Dewi Asimah, 2020, "Menjawab Kenadal Pembuktian dalam Penerapan Alat Bukti Elektronik", Jurnal Hukum Peratun Vol 3 No 2.

[3] Kustriyo and Aryani Witasari, "Abuse of Authority in Position and Redemption of Credit Fictitious Apparatus for Civil State (ASN) PD. Bank Perekreditan Rakyat (BPR) Sumber, Cirebon District", Jurnal Daulat Hukum $\begin{array}{llllll}\text { Vo } & 1 & \text { No } & 3 & \text { (2018) url: }\end{array}$ http://jurnal.unissula.ac.id/index.php/RH/article/view/3396.

[4] Maslikan \& Sukarmi, 2018, "Kewenangan Notaris Dalam Pembuatan Akta Otentik Berkaitan Dengan Kontrak Kerjasama", Jurnal Akta 5 (1)

[5] Sulaiman, Nur Arifudin, and Liliy, 2020, "Kekuatan Hukum Digital Signatur Sebagai Alat Bukti yang Sah Ditinjau dari Hukum Acara Perdata", Jurnal Risalah Hukum Vol 16 No 2.

[6] Triyanti, 2015, "Kekuatan Pembuktian Dokumen Elektronik Sebagai Pengganti Minuta Akta Notaris", Jurnal Repertorium Vol 11 No 2.

[7] V Letsoin, 2010, "Pengakuan Tandatangan Pada Dokumen Elektronik Dalam Pembuktian Hukum Acara Perdata di Indonesia”, Jurnal Sasi Vol 16 No 2.

\section{Books:}

[1] Abdul Halim Barkataullah and Teguh Prasetyo, 2005, Bisnis E-Commerce Studi Sistem Keamanan dan Hukum di Indonesia, Yogyakarta : Pustaka Pelajar

[2] Abdulkadir Muhammad. 2000. Hukum Perdata Indonesia. Bandung : PT Citra Aditya Bakti.

[3] Ahmaturrahman, 2005, Hukum Acara Perdata di Indonesia, Palembang : FH Press.

[4] Eddy O S Hiariej, 2012, Teori dan Hukum Pembuktian, Jakarta : Erlangga

[5] Edmon Makarim, 2003, Kompilasi Hukum Telematika, Divisi Buku Perguruan Tinggi, Jakarta:Rajagrafindo Persada.

[6] Edmon Makarim, 2013, Notaris dan Transaksi Elektronik, Jakarta: Rajawali Press.

[7] Hari Sasangka and Lily Rosita, 2003. Hukum Pembuktian dalam Perkara Pidana, Bandung : Mandar Maju.

[8] Oedharyo Soimin, 1999, Kitab Undang-Undang Hukum Perdata, Jakarta: Sinar Grafika.

[9] Subekti, 1995, Hukum Pembuktian, Jakarta : Pradnya Paramita.

[10] Zainudin Ali, 2014, Metode Penelitian Hukum, Jakarta: Sinar Grafika. 